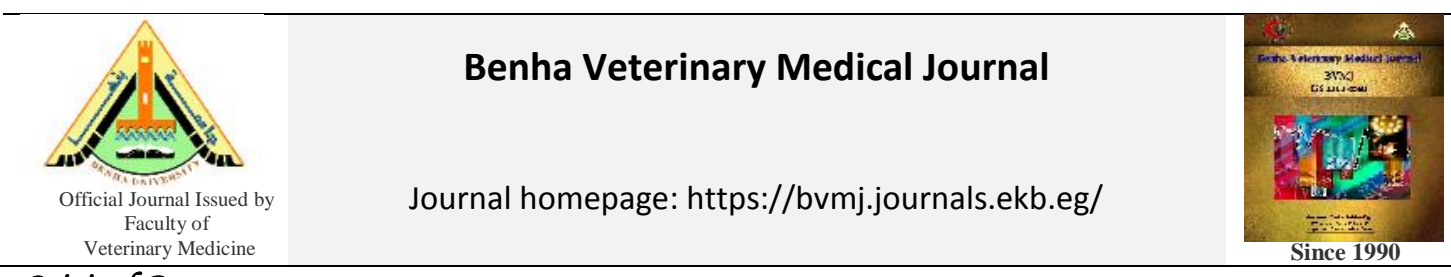

Original Paper

\title{
Isolation and identification of new sub-genotypes of virulent ND virus in broiler chickens in Qalybia governorate
}

\author{
Asmaa, I. Desouky ${ }^{1}$, Saad, A. E ${ }^{1}$., El shorbagy, M.A', Samah, E. Abodalal ${ }^{2}$ \\ ${ }^{I}$ Department of Avian and Rabbit diseases, Fac. Vet. Med. Benha University, Egypt. \\ ${ }^{2}$ Newcastle disease department veterinary serum and Vaccine Researcher Institute, Agriculture Research Center, Abbasia, Cairo, Egypt.
}

ARTICLE INFO

Keywords

F protein Cleavage site

Genotype VII

Newcastle Disease

Received 28/06/2020

Accepted 09/07/2020

Available On-Line

$01 / 10 / 2020$

\begin{abstract}
Newcastle disease (ND) is a highly contagious disease causing huge economic losses to the poultry industry due to high morbidities and mortalities. This study was aimed to isolate and characterize the new sub-genotype NDV strains in Qalybia Governorate during 2017 and 2019. Sixty-eight samples were collected from Sixty-eight broiler chicken flocks suffering from high mortality reach to $80 \%$ with distinctive clinical signs and post-mortem lesions of NDV. NDV strains isolated through inoculation in specific pathogen free (SPF) eggs and were identified by hemagglutination (HA) and hemagglutination inhibition (HI) techniques. There were 16/20 (about $80 \%$ ) of selected suspected farm were positive for NDV With HI test. These hemagglutinating agents were confirmed as NDV strains through molecular characterization using one step RT-PCR targeting the partial F-gene of NDV. Sequencing and phylogenetic analysis were successfully performed with eight NDV isolates which possessed the motif $112 \mathrm{R} / \mathrm{K}-\mathrm{R}-\mathrm{Q}-\mathrm{K} / \mathrm{RR} 116$ at the C-terminus of the F2 protein and F (phenylalanine) at residue 117, indicating that they are velogenic genotype. The present study revealed the circulation of NDV class II genotype VII in Qalybia chicken flocks
\end{abstract}

\section{INTRODUCTION}

Newcastle disease is one of the most devastating poultry disease which threat different poultry flocks inducing a high morbidity and mortality leading to severe losses in the poultry sector (Alexander, 2009).It is one of the notifiable diseases by OIE and consider the second highest endemic disease in many countries (OIE, 2012).Newcastle disease, caused by NDV which belongs to family Paramyxoviridae, Subfamily avulavirinae ,genus Orthoavulavirus (Kuhn et al., 2019). NDV is an enveloped virus containing linear, single-stranded, non-segmented and negative sense RNA (Mayo, 2002).

The virulence of NDV strains can be determined by genetic characterization on the basis of cleavage site of the fusion (F) protein resulting in strains of NDV are generally classified as velogenic, moderately mesogenic, and lentogenic pathotypes. The velogenic NDV strains have basic amino acids at the fusion $(\mathrm{F})$ cleavage site at residues 112 to 113 and 115 to 116 as well as a phenylalanine at residue 117 while lentogenic strains have

a monobasic cleavage site (Alexander, 2009).

Since 2000s, the circulating strain in field mainly belong to genotype VII (which consider velogenic strain), VNDV genotype VIId was firstly isolated in Egypt in 2012 by Radwan et al. (2013) from Giza Governorate, since that time NDV genotype VIId was isolated and characterized from recurrent outbreaks by many authors which gradually become the predominant strain in chicken flocks and have been causing significant economic losses (Qin et al, 2008;
Munir et al., 2012; Dimitrov et al., 2016).This study was performed to isolate and identify the velogenic NDV strains circulating mainly in commercial broiler farms in Qalybia Governorate.

\section{MATERIAL AND METHODS}

\subsection{Field samples}

Sixty-eight tissue samples including trachea, proventriculus, intestine, spleen, and cecal tonsils were collected from different broiler flocks from Qalybia Governorate which suffering from respiratory distress and greenish diarrhea. The most prominent P.M lesions vary between hemorrhage on gland tips of proventriculus (Fig. 1), hemorrhagic ulcer on cecal tonsil (Fig. 2), duodenal and rectal ulcer, tracheitis and some cases showed edematous proventriculus glands (Fig. 3). Pooling of tissue samples from each flock and preserved in sterile phosphate buffer saline (PBS) pH 7.0-7.4 containing gentamycin $(50 \mu \mathrm{g} / \mathrm{ml})$ and mycostatin (1000 units/ml) (OIE, 2012)

\subsection{Trials of virus isolation}

The homogenized tissue samples were centrifuged at $1000 \mathrm{xg}$ for $15 \mathrm{~min}$ at $4^{\circ} \mathrm{C}$ followed by filtration of supernatant by a $0.45 \mathrm{~m}$ and $0.22 \mathrm{~m}$ filter membrane (Farooq et al., 2014). The supernatant was inoculated at $0.1 \mathrm{ml}$ via the allantoic sac route of five 10-day-old SPF eggs (KoomOshiem, Fayoum, Agriculture Research Center, Ministry of Agriculture). Incubation of inoculated eggs at $37{ }^{\circ} \mathrm{C}$ for $96 \mathrm{hrs}$ with daily candling for embryo

* Corresponding author: Asmaa, I. Desouky, Department of Avian and Rabbit diseases, Fac. Vet. Med. Benha University, Egyp1 
vitality. Deaths recorded within $24 \mathrm{hrs}$ were discarded as nonspecific death. The eggs containing dead embryos were cooled at $4^{0} \mathrm{C}$ for harvesting of allantoic fluid for further identification.

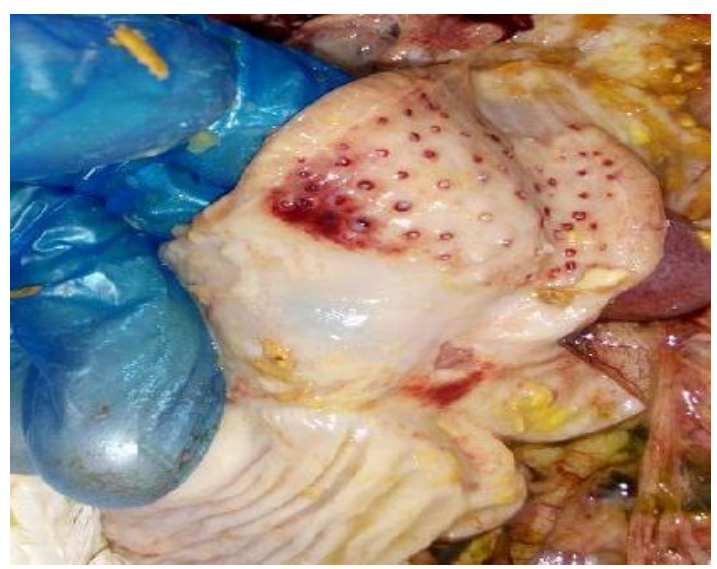

Fig (1) Broiler chickens aged 30 days old showed hemorrhage on gland tips of proventriculus

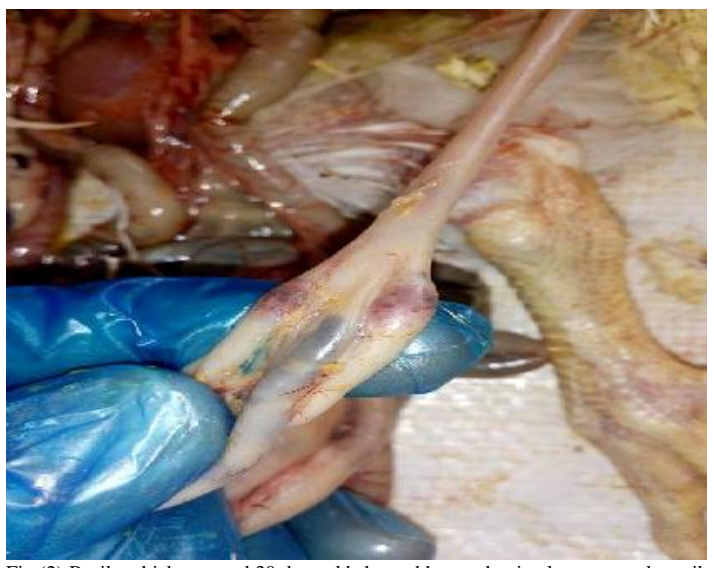

Fig (2) Broiler chickens aged 30 days old showed hemorrhagic ulcer on cecal tonsils.

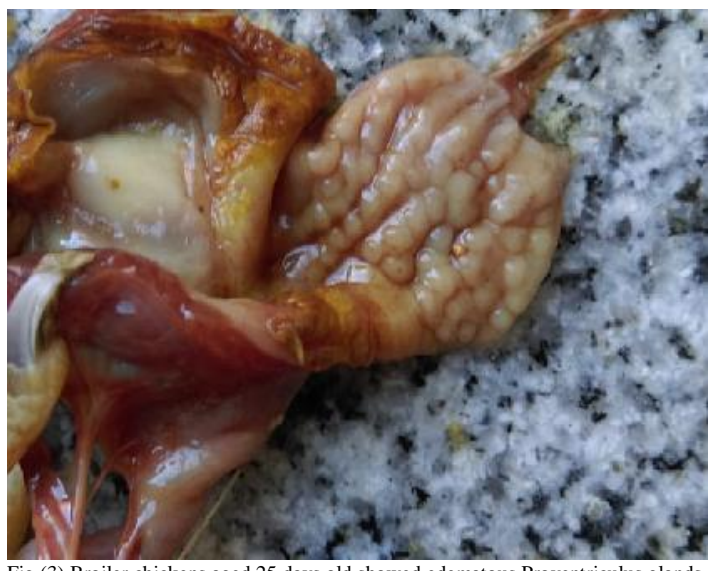

Fig (3) Broiler chickens aged 25 days old showed edematous Proventriculus glands

\subsection{Hemagglutination (HA) test:}

Allantoic fluids were collected from eggs containing dead embryos after $96 \mathrm{hrs}$. PI and subjected to the following tests:

2.3.1. Slide agglutination test which depend on mixing of $10 \%$ washed chicken red blood cells and infected allantoic fluid, the result appears through 1-2 minutes in form of minute agglutination or not.

2.3.2. Microtiter Plate agglutination test using $1 \%$ washed chicken RBCs, this method is based on a reaction between the virus and chicken RBCs in microtitre plate and detection of 4HA units which used in further identification using hemagglutination inhibition test (OIE, 2012).

\subsection{Hemagglutination inhibition (HI) test:}

HI test used for initial virus identification (Thayer et al., 2008). This method depended on a reaction between the virus and NDV specific antiserum produced in SPF chickens (prepared in Newcastle Disease Department, Veterinary Serum and Vaccine Research Institute, Abbasia, Egypt).

2.5. One step RT-PCR and gene sequencing: RNA from positive HA harvested allantoic fluids and identified with HI test was extracted by QIAamp Viral RNA Mini Kit (QIAGEN) based on the manufacturer's instructions. Using the following primers for the detection of partial F-gene and M-gene of vNDV through RT-PCR

Forward: F (M2): 5TGG-AGC-CAA-ACC-CGC-ACCTGC-GG 3

Reverse:(F2): 5' GGA-GGA-TGT-TGG-CAG-CAT-T3 that flanks a 766bp according to (Mase et al., 2002).

Quant one step RT-PCR Tiangen Kit (Tiangen Inc., China) was used according to the manufacturer's instructions , including 0.51 of each forward and reverse primers, 12.5 RT-PCR Master Mix , $3 \mu 1$ RNA template, 0.1251 QuantiTect RT Mix , $8.375 \quad l$ RNase Free Water and reverse transcription was carried out at $50^{\circ} \mathrm{C}$ for $30 \mathrm{~min}$, followed by an initial denaturation and Taq-polymerase activation at $95^{\circ} \mathrm{C}$ for $15 \mathrm{~min}, \mathrm{cDNA}$ was then amplified with 30 cycles of $95^{\circ} \mathrm{C}$ for $30 \mathrm{sec}, 55^{\circ} \mathrm{C}$ for $40 \mathrm{sec}$ and $72^{\circ} \mathrm{C}$ for $45 \mathrm{sec}$, followed by a final extension step at $72^{\circ} \mathrm{C}$ for 10 min. RTPCR product was visualized by electrophoresis in $1.5 \%$ agarose in $1 \mathrm{X}$ TAE, ethidium bromide was added to a concentration of $0.5 \mu \mathrm{g} / \mathrm{ml}$ for nucleic acid visualization. DNA fragments were tested under UV light. Eight NDV isolates were selected for sequencing and phylogenetic characterization, the target bands of specific size were excised from the gel and purified with the QIAquick gel extraction kit (QiagenInc, Valencia, CA) according to the manufacturer instructions and the DNA was quantified and sequenced directly using automated sequencing machine (Applied Biosystems, Foster City, CA). A BLAST search was conducted for each sequence (http://www.ncbi.nlm.nih.gov/BLAST) . A comparative analysis of sequences was performed using the CLUSTAL $\mathrm{W}$ multiple sequence alignment program, version 1.83 of MegAlign module of Lasergene DNA Star software Pairwise, which was designed by (Thompson et al., 1994) and phylogenetic analysis were done using maximum likehood, neighbour joining and maximum parsimony in MEGA6 (Tamura et al., 2013).

\section{RESULTS}

3.1. Virus isolation and hemagglutination:

There were 20 samples selected from suspected 68 farms as they showed severe signs, pathognomonic lesions of Newcastle disease virus, different ages, from different regions located at Qalybia Governorate , and selected from different vaccinated and non-vaccinated flocks . About $20 / 20(100 \%)$ samples were positive for isolation of hemagglutinating viruses in embryonated eggs. The inoculated embryos showed subcutaneous hemorrhage as shown in Fig. (4). 


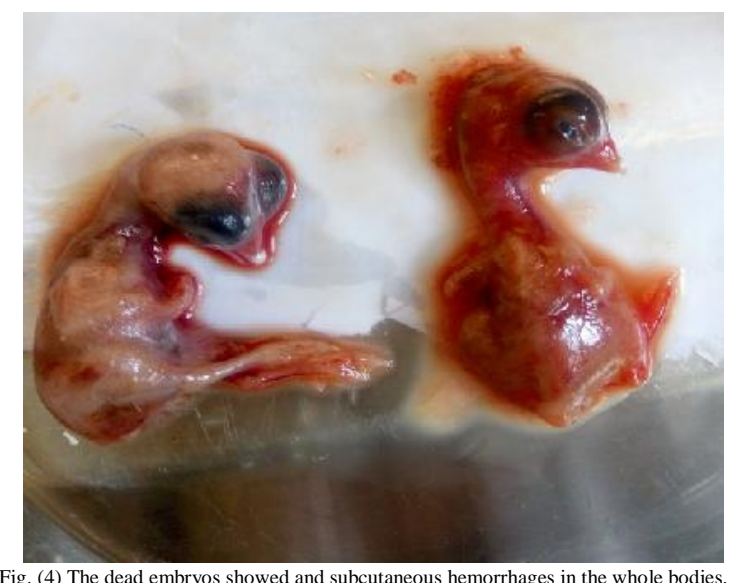

Slide agglutination test showed minutes agglutination within 1-2 minutes and the HA unit of allantoic fluid ranged from $1 / 8$ to $1 / 128$ as shown in table (1).

Table 1 Results of HA, HI and RT-PCR of collected allantoic fluids for detection of NDV

\begin{tabular}{|c|c|c|c|c|}
\hline Serial No. & Sample No. & Micro plate HA $\log 2$ & HI titre $\log 2$ & RT-PCR \\
\hline 1 & 1 & 4 & 3 & $-\mathrm{ve}$ \\
\hline 2 & 6 & 6 & 9 & $+\mathrm{ve}$ \\
\hline 3 & 7 & 5 & 6 & $+\mathrm{ve}$ \\
\hline 4 & 10 & 2 & 0 (-ve NDv) & --- \\
\hline 5 & 11 & 4 & 8 & $+\mathrm{ve}$ \\
\hline 6 & 31 & 7 & 8 & $+\mathrm{ve}$ \\
\hline 7 & 32 & 7 & 9 & $+\mathrm{ve}$ \\
\hline 8 & 33 & 5 & 4 & $+\mathrm{ve}$ \\
\hline 9 & 38 & 3 & 0 (-ve NDv) & --- \\
\hline 10 & 39 & 4 & 0 (-ve NDv) & -- \\
\hline 11 & 44 & 3 & 6 & $+\mathrm{ve}$ \\
\hline 12 & 47 & 6 & 9 & $+\mathrm{ve}$ \\
\hline 13 & 48 & 6 & 0 (-ve NDv) & --- \\
\hline 14 & 49 & 6 & 8 & $+\mathrm{ve}$ \\
\hline 15 & 62 & 5 & 7 & $+\mathrm{ve}$ \\
\hline 16 & 64 & 5 & 7 & $+\mathrm{ve}$ \\
\hline 17 & 65 & 5 & 8 & $+\mathrm{ve}$ \\
\hline 18 & 66 & 5 & 8 & $+\mathrm{ve}$ \\
\hline 19 & 67 & 4 & 7 & $+\mathrm{ve}$ \\
\hline 20 & 68 & 6 & 9 & $+\mathrm{ve}$ \\
\hline
\end{tabular}

3.2. Hemagglutination inhibition test:

The positive HA allantoic fluids $(n=20)$ were submitted to HI test ( $\alpha$ technique constant-serum diluted-antigen) for identification of NDV. The NDV was detected in 16/20 samples with a percentage of $80 \%$ using specific ND antiserum as shown in table (1).

\subsection{Results of genetic analysis}

3.3.1. Molecular identification by one step conventional RT-PCR

About 16 HA positive allantoic fluids were screened for qualitative detection and confirmation of NDVs using specific one step RT-PCR. About15 allantoic fluids were confirmed as NDV by RT-PCR giving specific amplicon size at $766 \mathrm{bp}$ of matrix and fusion gene including the F0 cleavage site (Table 2 and Fig 5).

\subsubsection{Sequence and phylogenetic analysis}

Eight representative NDV isolates were chosen for further investigation by sequencing. The obtained results indicated that the eight isolates possessed the $\mathrm{F}$ protein cleavage site amino acid motif 112 R/K-R-Q-K/RR116 and phenylalanine at residue 117 indicated they are velogenic (Fig. 5 and 6). The phylogenic analysis of the eight NDV isolates indicated that, strains 1-7 clustered together with high relationship with previously isolated Egyptian strains Genotype VIIb /2016/Egy-BehGene bank accession No(MH899931,MH899940 and Mh899932) and $8^{\text {th }}$ strain lies between Japanese strain isolated from pheasant(AB070395 Genotype VII velogenic) and Genotype VII from China(FJ608350/DFQS/Beijing) as showed in (Fig.7). Eight identified strains were published on Gene bank and had accession numbers (Table 2).

In the Table 3 strains 1-7 showed high identity (97.6$100 \%$ ) between them where strain 8 had lower identity (92.1-93.5\%) with them and the homology with the other NDV strains ranged from (91.6-99.5\%), the results also indicated that these eight isolates are far from vaccine strains which are commonly used in the poultry field to protect the chicken from infection with NDV.

\section{DISCUSSION}

Newcastle disease (ND) is one of the most severe avian infectious disease which responsible for devastating outbreaks in commercial poultry flocks all over the world. Nowadays NDV genotype VII gradually become the predominant strain in chicken flocks leading to severe economic losses to poultry sector. The disease becomes endemic in commercial broiler poultry farms however application of various chickens' vaccination strategies, (Qin et al., 2008; Munir et al., 2012; Dimitrov et al., 2016). Our study was conceded to isolate and characterize the NDV strains which responsible for huge outbreaks in broiler poultry farms in Qalybia Governorate. In the current study the investigated broiler flocks were suffering from variable mortalities (6-80\%) with clinical signs including respiratory signs as nasal discharge and gasping, and, periorbital edema, nervous signs characterized by torticollis and also greenish colored diarrhea. At necropsy, hemorrhagic tracheitis, hemorrhagic cecal tonsils and hemorrhages on the tip of the glands of proventriculus.

\begin{tabular}{|c|c|c|c|c|c|c|}
\hline Strain No. & Abbreviation & Genotype & Host & Virulence & Cleavage site of F protein 112 RRQKR116F & $\begin{array}{l}\text { Gene Bank Accession } \\
\text { No }\end{array}$ \\
\hline 1 & NDV/EG-Q/Ch/6/2019 & VII b & Chicken & Virulent & RRQKRF & MN137989 \\
\hline 2 & NDV/EG-Q/Ch/31/2018 & VII b & Chicken & Virulent & RRQKRF & MN137990 \\
\hline 3 & NDV/EG-Q/Ch/1 1/2018 & VII b & Chicken & Virulent & RRQKRF & MN137991 \\
\hline 4 & NDV/EG-Q/Ch/47/2019 & VII b & Chicken & Virulent & RRQKRF & MN137992 \\
\hline 5 & NDV/EG-Q/Ch/4/2019 & VII b & Chicken & Virulent & RRQKRF & MN458502 \\
\hline 6 & NDV/EG-Q/Ch/5/2019 & VII b & Chicken & Virulent & RRQKRF & MN458503 \\
\hline 7 & NDV/EG-Q/Ch/9/2018 & VII b & Chicken & Virulent & RRQKRF & MN458504 \\
\hline 8 & NDV/EG-Q/Ch/12/2018 & VII b & Chicken & Virulent & RRQKRF & MN458505 \\
\hline
\end{tabular}


Sometimes edematous proventricular glands, hemorrhagic ulcers in the wall of intestine were common with virulent viscerotropic NDV. These findings confirmed the suspicious of NDV infection as previously mentioned by many authors (Alexander, 2009; Susta et al., 2010; Radwan et al., 2013; Ewies et al., 2017).

Virus isolation was attempted on SPF ECE which represent an extremely sensitive method for the isolation of NDV (Alexander, 1989; OIE, 2008). The prepared samples inoculated via allantoic sac route revealed hemorrhagic dead embryos 48-96 hours PI as showed in Fig. (5) after first passage as detected by Megahed et al. (2018). The presence of the virus was tested for HA by rapid plate HA test revealed that, all inoculated samples demonstrated positive hemagglutination activity in the harvested allantoic fluid from the first passage.

These samples were submitted for HI testing using specific antibody for NDV and the data reveal that $16(80 \%)$ of total samples were positive to NDV as mentioned in table1 this result was nearly coincided with (Farooq et al., 2014).
These hemagglutinating agents were confirmed as NDV strains through molecular characterization using RT-PCR targeting the partial F-gene and M-gene of NDV using one step RT-PCR kit and two primers according to Mase et al. (2002); $15(75 \%)$ out of total 20 samples were positive NDV. Similar result was recorded by Alkhalefa et al. (2017), who found that $15(75 \%)$ out of 20 tested samples were positive NDV. Nucleotides sequence and phylogenetic studies which represent the main molecular determinant of NDV virulence of F protein were performed to our eight isolates (Aldous and Alexander, 2001; Orabi et al., 2017). The result of sequence analysis revealed that our eight isolates had the multiple basic amino acids sequences ${ }^{112}{ }^{2 R Q K R F}{ }^{117}$ located at the C-terminus of the F1 protein and phenylalanine $(\mathrm{F})$ at the $\mathrm{N}$-terminus of the $\mathrm{F} 2$ protein as mentioned in tables (2 and 3) and fig. (9), these results classify them as virulent strains related to the definition of OIE (OIE, 2012).Phylogenetic analysis showed that eight isolates were grouped with class II genotype VIIb this result was consistent with (Saad et al., 2017).
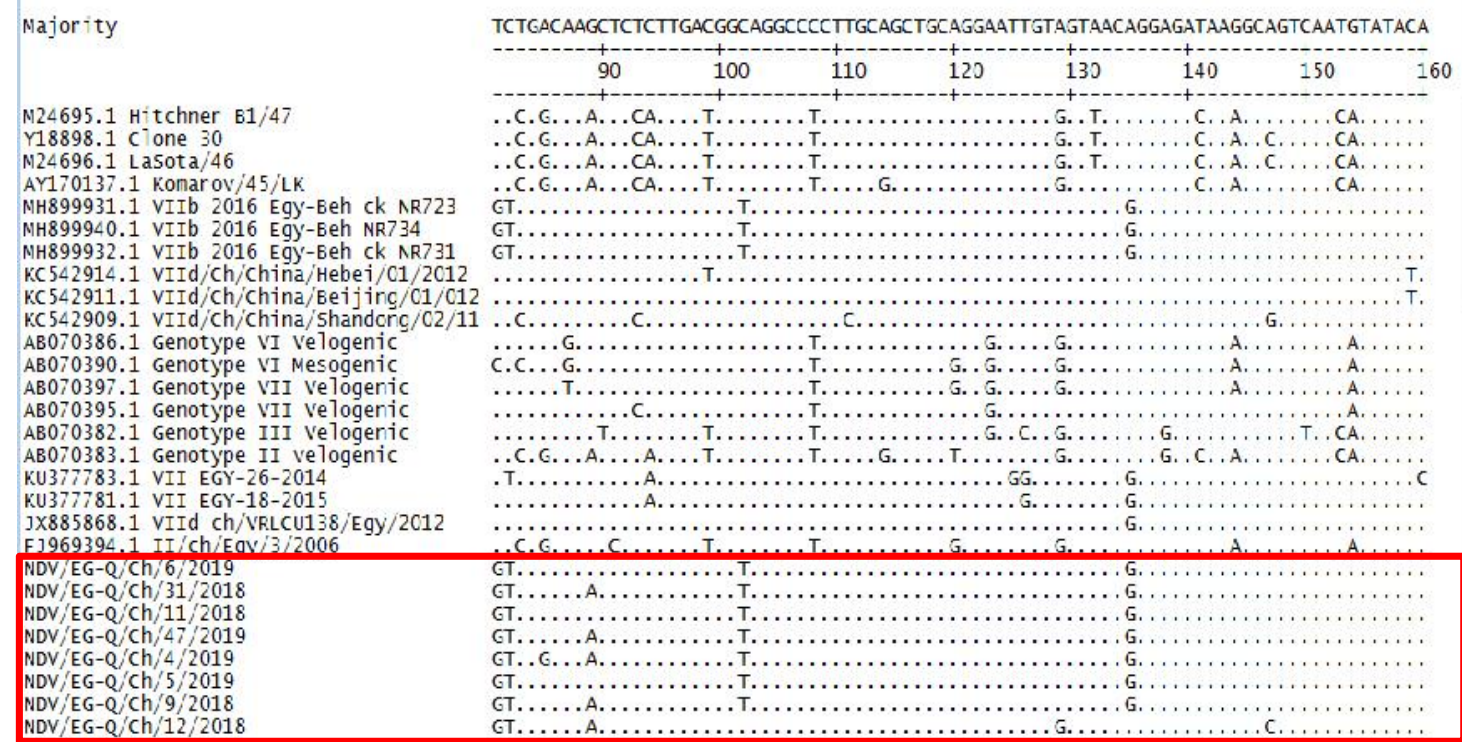

Fig. (5) Nucleotides sequences of the partial F protein of the isolated NDV strains in comparison with other NDV isolates selected from gene bank.
LEAYNRTLTTLLTPLGDSIRKIQGSVSTSGGRRQKRFIGAVIG

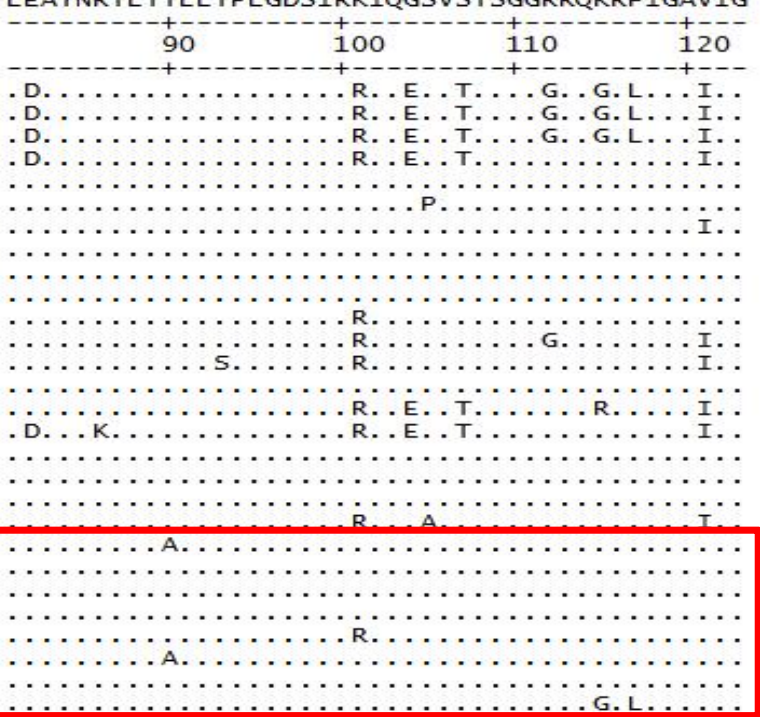

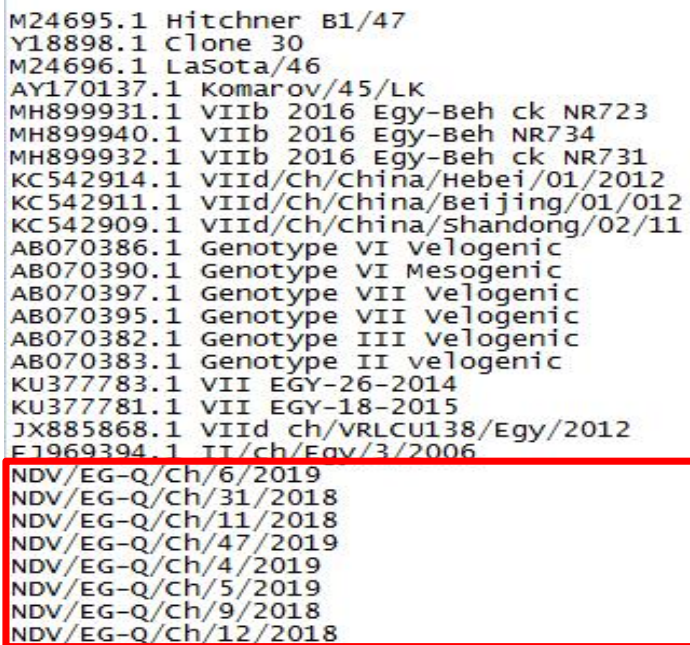

Fig. 6 Deduced amino acid sequences of F partial F protein of the isolated NDV strains in comparison with other NDVs isolates selected from gene bank 


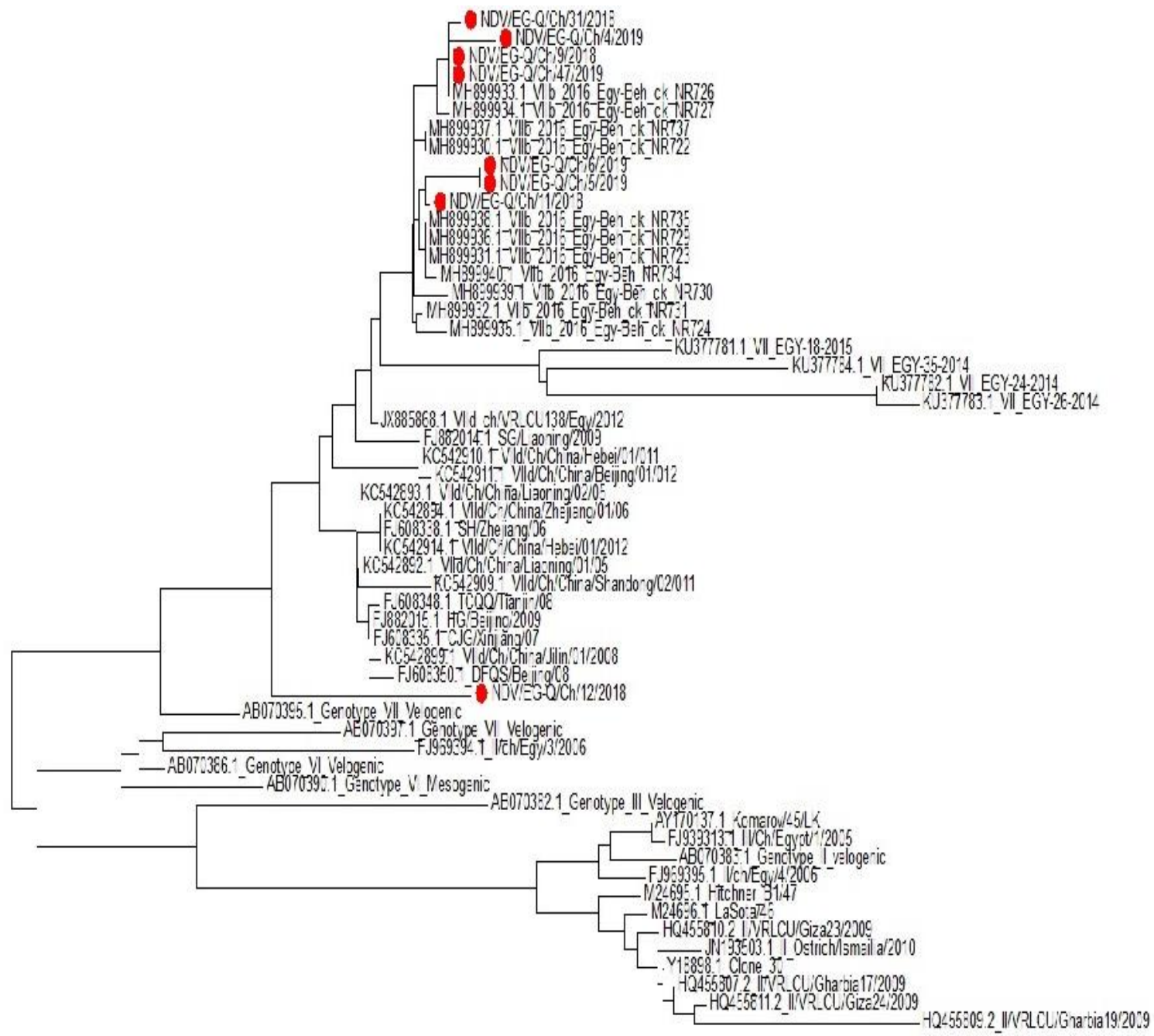

Fig. 7 Phylogenetic analysis of F gene amino acid sequences of NDV isolated from chickens in Egypt and other sequences available on Gen Bank. The tree was constructed via multiple alignments of amino acids sequences of $\mathrm{F}$ gene and was analyzed by neighbor-joining analysis with 1000 bootstrap replicates, in this study are marked with red spots

Table (3) Amino acid identity of NDV isolates with NDV strains and NDV vaccines

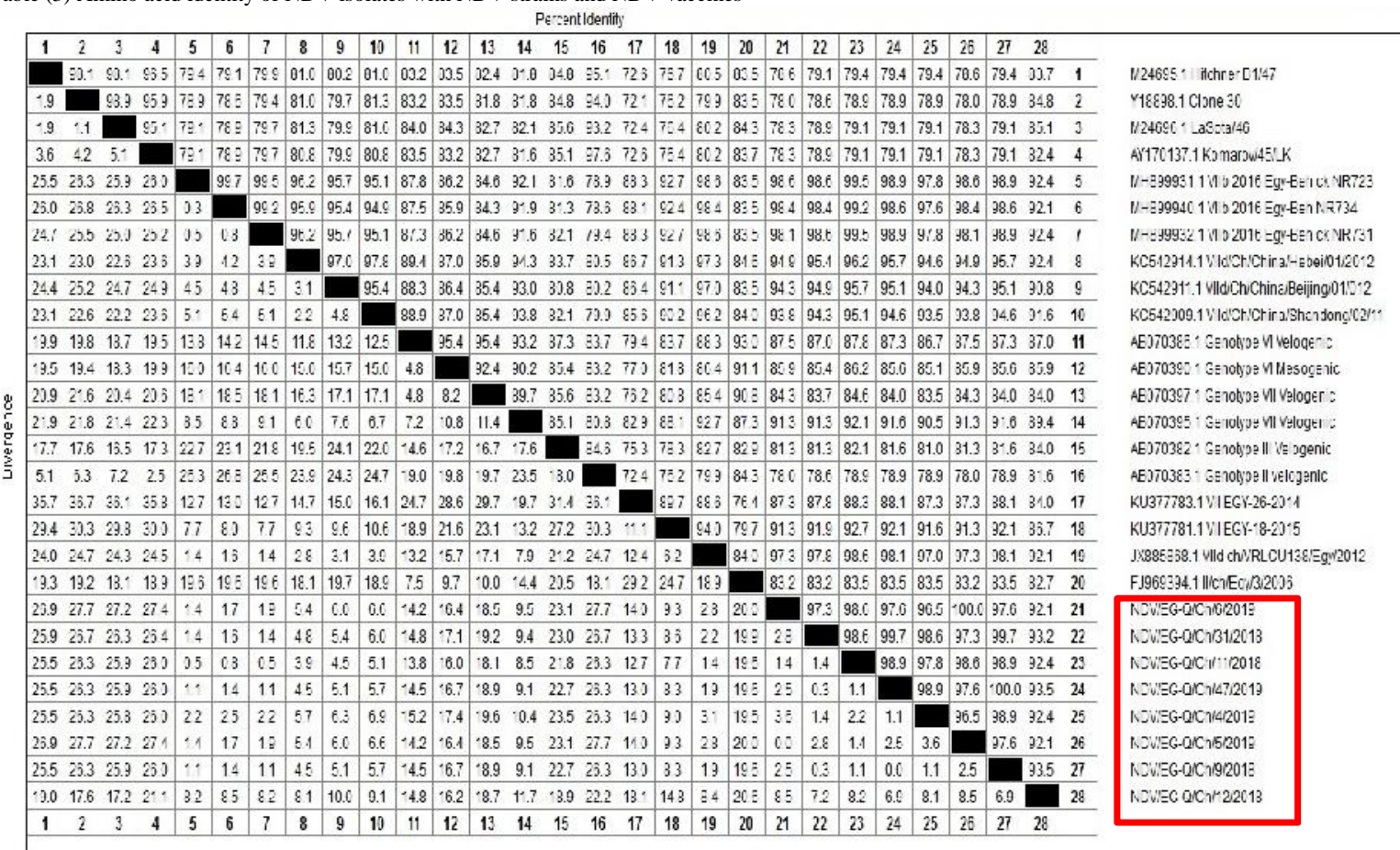




\section{CONCULSION}

Newcastle disease virus still circulating among chicken flocks with breakage of several vaccination programs, especially genotype VII which become the predominant strain in the field causing economic loss in poultry industry. So continuous monitoring of epidemiological status of the disease with complete genome sequences of the virus is recommended in addition to effective vaccination protocol to help in controlling of the disease.

\section{REFERENCES}

1. Alexander, D.J. (1989). Newcastle disease. In: A laboratory manual for the isolation and identification of avian pathogens. American Association of Avian Pathologists. Pp. 114-120.

2. Alexander, D.J. (2009): Ecology and epidemiology of Newcastle disease. In: Capua, I. and Alexander, D.J. (Eds.), Avian Influenza and Newcastle Dis- ease, a Field and Laboratory Manual. Springer-Verlag, Italy, Pp. 19- 26.

3. Alkhalefa, N.; Shawky, E. K. and Desouky, A. Y. (2017): Molecular characterization of Newcastle disease virus (NDV) genotype VII isolated from broiler chicken flocks in Egypt. Life Sci. J., 14(5): 79,232-237..

4. Aldous, E.W. and Alexander, D.J. (2001): Technical review: Detection and differentiation of Newcastle disease virus (avian paramyxovirus type 1). Avian Pathol., 30(2): 117-128.

5. Dimitrov, K.M.; Afonso, C.L.; Yu, Q. and Miller, P.J.(2016):Newcastle disease vaccines-A solved problem or a continuous challenge? Vet. Microbiol, 206:126-136.

6. Ewies, S. S.; Ali, A.; Tamam, S. M. and Madbouly, H. M. (2017): Molecular characterization of Newcastle disease virus (genotype VII) from broiler chickens in Egypt. BeniSuef University Journal of Basic and Applied Sciences, 6: 232-237.

7. Farooq, M.; Saliha, U.; Munir, M. and Khan,Q. M. (2014) : Biological and genotypic characterization of the Newcastle disease virus isolated from disease outbreaks in commercial poultry farms in northern Punjab, Pakistan. Virology, 3: 3039.

8. Kuhn, J.H.; Wolf, Y.I.; Krupovic, M.; Zhang, Y.Z.; Maes, P.; Dolja, V.V. and Koonin, E.V.( 2019):Classify viruses - the gain is worth the pain, Nature 566, 318-320.

9. Mase, M.; Imai, K.; Sanada, Y.; Sanada, N.; Yuasa, N.; Imada, T.; Tsukamoto, K. and Yamaguchi, S. (2002): Phylogenetic Analysis of Newcastle Disease Virus Genotypes Isolated in Japan. J. Clin. Microb., 40(10): 38263830 .

10. Mayo, M.A. (2002): A summary of taxonomic changes recently approved by ICTV. Archives of Virology, 147: 1655-1656.
11. Megahed, M. M.; Eid, A. A. M.; Mohamed, W. and Hassanin, Ola. (2018): Genetic Characterization of Egyptian Newcastle Disease Virus Strains Isolated From Flocks Vaccinated Against Newcastle Disease Virus, 20142015.Slov Vet Res, 55 (20): 17-29.

12. Munir, M.; Abbas, M.; Khan, M.T.; Zohari, S. and Berg, M. (2012): Genomic and biological characterization of a velogenic Newcastle disease virus isolated from a healthy backyard poultry flock in 2010. Virology Journal, 9: 46.

13. OIE, (2008): Newcastle disease. Chapter 2.3.14. In Manual of Diagnostic Tests and Vaccines for Terrestrial Animals (Mammals, Birds and Bees), 6th ed., Paris, France, 576- 589.

14. OIE. (2012):Newcastle disease. Chapter2.3.14. OIE manual of standards for diagnostic test and vaccines. Version adopted by world Assembly of Delegates of OIE in May 2012.http://www.oie.int/fileadmin/Home/eng/Health standers/tahm/2.03.14 NEWCASTLE DIS.pdf.

15. Orabi, A.; Hussein, A.; Saleh, A.A. ; Abu El-Magd, M. and Munir, M. (2017): Evolutionary insights into the fusion protein of Newcastle disease virus isolated from vaccinated chickens in 2016 in Egypt Arch Virol, 162:3069-3079.

16. Qin, Z. M.; Tan, L. T.; Xu, H. Y.; Ma, B. C.; Wang, Y. L.; Yuan, X. Y. and Liu W. J.(2008): Pathotypical characterization and molecular epidemiology of Newcastle disease virus isolates from different hosts in China from 1996 to 2005. J. Clin. Microbiol. 46:601-611.

17. Radwan, M.M; Darwish, S.F.; El-Sabagh, I.M.; El-Sanousi, A.A. and Shalaby. M.A. (2013): Isolation and molecular characterization of Newcastle disease virus genotypes II and VIId in Egypt between 2011 and 2012. Virus Genes, 47 (2):311- 316.

18. Saad, A. M.; Samy, A.; Soliman, M. A.; Arafa, A.; Zanaty, A.; Hassan, M. K.; Sultan, A. H.; Bazid, A. I. and Hussein, A. H.(2017): Genotypic and pathogenic characterization of genotype VII Newcastle disease viruses isolated from commercial farms in Egypt and evaluation of heterologous antibody responses. Arch Virol., 162:1985-1994.

19. Susta, L.; Miller, P.; Afonso, C. and Brown, C. C. (2010): Clinicopathological characterization in poultry of three strains of Newcastle disease virus isolated from recent outbreaks. Vet. Pathol., 48:349-360.

20. Tamura, K.; Stecher, G.; Peterson, D.; Filipski, A. and Kumar, S. (2013): MEGA6: molecular evolutionary genetics analysis version 6.0. Mol. Biol. 30: 2725-2729.

21. Thayer, S.G. and Beard, C.W. (2008): Serologic procedures. In: A Laboratory Manual for the identification and characterization of avian pathogens. Dufour-Zavala, L. (Ed.), Aaap, Jacksonville, Florida. Pp: 222-229.

22. Thompson, J.D.; Higgins, D.G. and Gibson, T.J. (1994): CLUSTAL W: improving the sensitivity of progressive multiple sequence alignment through sequence weighting, position-specific gap penalties and weight matrix choice. Nucleic Acids Research, 22(22): 4673-4680. 